\title{
IS THE NEW
}

KEYNESIAN IS

\section{CURVE}

\section{STRUCTURAL?}

by Livio Stracca 
EUROPEAN CENTRAL BANK

EUROSYSTEM

\section{WORKING PAPER SERIES}

NO I236 / AUGUST 2010

\section{IS THE NEW KEYNESIAN IS CURVE \\ STRUCTURAL?'}

by Livio Stracca ${ }^{2}$

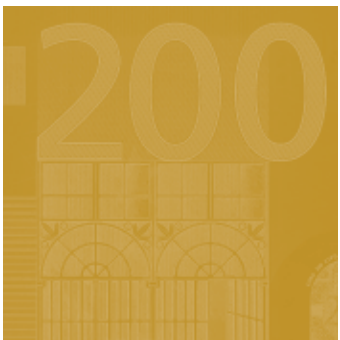

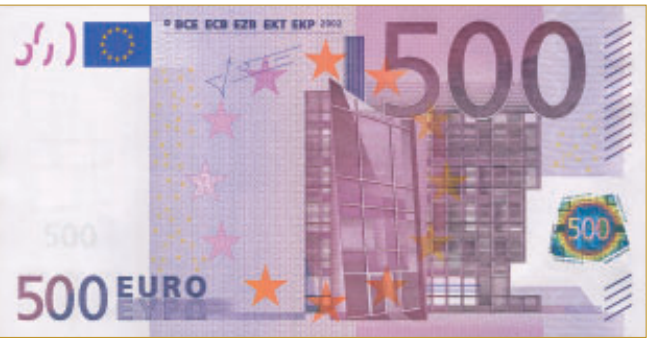

In 2010 all ECB

publications

taken from the

$€ 500$ banknote.
NOTE: This Working Paper should not be reported as representing the views of the European Central Bank (ECB).

The views expressed are those of the author and do not necessarily reflect those of the $E C B$. 
CC European Central Bank, 2010

\section{Address}

Kaiserstrasse 29

60311 Frankfurt am Main, Germany

Postal address

Postfach 160319

60066 Frankfurt am Main, Germany

Telephone

+496913440

Internet

http://www.ecb.europa.eu

Fax

+496913446000

All rights reserved.

Any reproduction, publication and reprint in the form of a different publication, whether printed or produced electronically, in whole or in part, is permitted only with the explicit written authorisation of the ECB or the author.

Information on all of the papers published in the ECB Working Paper Series can be found on the ECB's website, http://www. ecb.europa.eu/pub/scientific/wps/date/ html/index.en.html

ISSN 1725-2806 (online) 


\section{CONTENTS}

Abstract 4

Non-technical summary 5

1 Introduction 7

2 Baseline specification 9

3 Extended version and heterogeneity analysis I|

3.1 Extended specifications I|

3.2 Country heterogeneity I3

4 Data 14

5 The empirical model 15

6 Results 16

6.1 Backward looking IS curve 16

6.2 Baseline forward-looking IS curve $\quad 17$

6.3 Extended specifications 18

6.4 Robustness 19

6.5 Country heterogeneity 20

6.6 Some caveats and qualifications 22

7 Conclusions 23

References $\quad 25$

Tables $\quad 29$ 


\begin{abstract}
There is already a small literature emphasising the empirical failure of the New Keynesian IS curve, but it is not yet known if this failure reflects empirical problems associated with small samples or is rather a structural weakness of the underlying model. To address this question, in this paper I estimate the New Keynesian IS curve for output and consumption and several possible extensions on panel data from 22 OECD countries over 40 years of data. I also evaluate whether the key parameters of the IS curve change according to countries' economic and financial structure. The main finding is that output and consumption are mainly forward looking, and this is a very robust feature of the data. At the same time, I find little evidence in favour of the traditional specification where the real interest rate enters with a negative sign due to intertemporal substitution; on the contrary, it is typically either insignificant or wrongly signed. Overall, I conclude that the New Keynesian IS curve, at least in its most common formulations, is not structural and is overwhelmingly rejected by the data.
\end{abstract}

Keywords: IS curve, New Keynesian model, panel data, Instrumental variables. JEL: E21, E44, E52. 


\section{Non-technical summary}

The New Keynesian IS curve is a mainstay of modern macroeconomic models but is relatively under-researched compared with the New Keynesian Phillips curve. In addition, most of the empirical work reaches negative results. Fuhrer and Rudebusch (2004), in particular, point out that it is highly problematic to find robust evidence, at least on US data, of the expected negative sign for the real interest rate together with a significant role for expected output or consumption, independent of the estimation method chosen; moreover, they highlight that GMM estimates are problematic due to weak instruments, and that maximum likelihood estimation may be preferable. Other papers have argued that, rather than the real interest rate, measures of narrow or broad money appear to be more successful in empirical IS curves, which are typically backward looking rather than forward looking as implied by New Keynesian models Goodhart and Hofmann (2005) find that adding asset prices appears to be fundamental for the real interest rate to enter the IS curve with the expected negative coefficient, and that is only true, again, in a purely backward-looking specification. Angeloni and Ehrmann (2007) estimate the IS curve on panel data from 12 euro area countries on a sample period from 1998 to 2003, and can only estimate a backward looking version of the curve. A related literature deals with the failure of the consumption Euler equation which is the basis of most DSGE models used for monetary policy analysis; the classic reference here is Campbell and Mankiw (1991) but the problem has been revisited more recently by Muellbauer (2010), who emphasises the "inconvenient truth" of the rejection of the classic consumption Euler equation.

The key question addressed in this paper is whether the empirical rejection of the New Keynesian IS curve reflects data problems such as small samples or is rather a reflection of a more fundamental weakness of the underlying model. The hypothesis that I want to test in this paper is whether a relationship with the key qualitative characteristics of the New Keynesian IS curve (namely output or consumption at least partly forward looking, negative real interest rate elasticity) is "structural" in the sense that it holds at least for most countries in most sample periods.

The contribution of this paper is threefold:

- First, I aim at increasing the statistical power of the empirical exercise by estimating the New Keynesian IS curve, as well as several possible extensions, pooling information from a panel of 22 OECD countries over almost 40 years of data.

- Second, I address the question of the stability of the relationship in the sense of Lucas (1976). For the New Keynesian IS curve to be a good model for policy-makers, its structural parameters should not vary in a systematic manner over time and according to countries' structural characteristics. If, say, parameter of the IS curve is systematically different according to the realisation of a certain variable $\mathrm{X}$, then the latter variable should be incorporated in a good theory that can be reliably used by policy-makers.

- Finally, in this paper I take a serious look at the economic significance of the inclusion of variables in the IS curve; it is argued, in particular, that for variable $\mathrm{Y}$ to be important in a good model for the IS curve for policy makers, its impact should be (i) robust to changes in the specification, sample and to some extent estimation method, and (ii) materially contribute to the fit and performance of the equation. Otherwise, it can be argued that the considered variable should be dropped from the reference model. 
The main results of the paper are as follows:

- There is very robust evidence that the IS curve is predominantly forwardlooking and that it is therefore generally misleading to estimate it in backward looking fashion. This feature appears to be little affected by structural differences across countries and over time. This confirms a cornerstone of the New Keynesian model, i.e. that agents are predominantly forward-looking in their decisions.

- However, the key forcing variable in such models, the ex ante real interest rate, is often statistically insignificant or wrongly signed, at least compared with baseline models where the inter-temporal substitution effect dominates over the income or wealth effect and the interest rate elasticity of output is negative. Results for other potential driving variables are more mixed.

- Overall, the main conclusion of the paper is that the evidence strongly points to the baseline New Keynesian IS curve not being a structural relationship. 


\section{Introduction}

The global financial crisis has exposed economists' less than perfect understanding of the determinants of consumption and output at an international level. Mainstream New Keynesian models used for monetary policy analysis identify a forward looking IS curve where output (or consumption) is driven by expectations of future output (consumption) as well as the ex ante real interest rate; habit formation may also create a role for lagged output (consumption). It is hard to see how these determinants may explain, by themselves, the global recession of 2009, not even close.

Compared with the New Keynesian Phillips curve, there has been much less empirical work on the New Keynesian IS curve. Moreover, most of the empirical work reaches negative results. Fuhrer and Rudebusch (2004), in particular, point out that it is highly problematic to find robust evidence, at least on US data, of the expected negative sign for the real interest rate together with a significant role for expected output or consumption, independent of the estimation method chosen; moreover, they highlight that GMM estimates are problematic due to weak instruments, and that maximum likelihood estimation may be preferable. Other papers have argued that, rather than the real interest rate, measures of narrow or broad money appear to be more successful in empirical IS curves, which are typically backward looking rather than forward looking as implied by New Keynesian models (see Nelson 2002; Hafer, Haslag and Jones 2007; Hafer and Jones 2008). Goodhart and Hofmann (2005) find that adding asset prices appears to be fundamental for the real interest rate to enter the IS curve with the expected negative coefficient, and that is only true, again, in a purely backward-looking specification. Angeloni and Ehrmann (2007) estimate the IS curve on panel data from 12 euro area countries on a sample period from 1998 to 2003, and can only estimate a backward looking version of the curve, with the real interest rate only significant at the 10 per cent level. A related literature deals with the failure of the consumption Euler equation which is the basis of most DSGE models used for monetary policy analysis; the classic reference here is Campbell and Mankiw (1991) but the problem has been revisited more recently by Muellbauer (2010), who emphasises the "inconvenient truth" of the rejection of the classic consumption Euler equation. ${ }^{1}$

There is no doubt that the inter-temporal IS curve is a mainstay of New Keyne-

\footnotetext{
${ }^{1}$ See Muellbauer (2010), page 17 . Note that in none of the consumption equations estimated by Muellbauer is the real interest rate term significant at the $5 \%$ confidence level.
} 
sian models used for monetary policy analysis, most of which stand or fall depending on whether the New Keynesian IS curve is a realistic representation of the data. It is therefore of paramount importance for macroeconomics and monetary economics that the empirical problems that have been identified in the literature are properly understood and addressed. In particular, the key question is whether the empirical rejection of the New Keynesian IS curve reflects data problems such as small samples (as emphasised by Fuhrer and Rudebusch 2004) or is rather a reflection of a more fundamental weakness of the underlying model. The hypothesis that I want to test in this paper is whether a relationship with the key qualitative characteristics of the New Keynesian IS curve (namely output or consumption at least partly forward looking, negative real interest rate elasticity) is "structural" in the sense that it holds at least for most countries in most sample periods.

Against this background, the contribution of this paper is threefold. First, I aim at increasing the statistical power of the empirical exercise by estimating the New Keynesian IS curve, as well as several possible extensions, pooling information from a panel of 22 OECD countries over almost 40 years of data. Since this provides more than 3,000 quarterly observations, the analysis might lead to sharper results in the estimation of key structural parameters of the IS curve, compared with previous studies. Second, I address the question of the stability of the relationship in the sense of Lucas (1976). For the New Keynesian IS curve to be a good model for policy-makers, its structural parameters should not vary in a systematic manner over time and according to countries' structural characteristics. If, say, parameter $\eta$ of the IS curve is systematically different according to the realisation of a certain variable $X$, then the latter variable should be incorporated in a good theory that can be reliably used by policy-makers. Using panel data is very helpful in this respect since it increases the amount of variation in the financial and economic structure, since this is typically larger across countries than over time in an individual country. Finally, in this paper I take a serious look at the economic significance of the inclusion of variables in the IS curve; it is argued, in particular, that for variable $Y$ to be important in a good model for the IS curve for policy makers, its impact should be (i) robust to changes in the specification, sample and to some extent estimation method, and (ii) materially contribute to the fit and performance of the equation. Otherwise, it can be argued that the considered variable should be dropped from the reference model. 
I find very robust evidence that the IS curve is predominantly forward-looking and that it is therefore generally misleading to estimate it in backward looking fashion. This feature appears to be little affected by structural differences across countries and over time. Therefore, this result confirms a cornerstone of the New Keynesian model, i.e. that agents are predominantly forward-looking in their decisions. However, the good news for the New Keynesian IS curve end here. First and foremost, I find that the key forcing variable in such models, the ex ante real interest rate, is often statistically insignificant or wrongly signed, at least compared with baseline models where the intertemporal substitution effect dominates over the income or wealth effect and the interest rate elasticity of output is negative. Results for other potential driving variables are more mixed. Real money balances are almost invariably insignificant. House prices are significant only in the backward looking version of the IS curve, but disappear in more forward looking versions. Turning to open economy issues, the real effective exchange rate and the terms of trade are significant and correctly signed in some specifications, but not in others. Finally, the real share price is highly statistically significant but enters with a negative sign, indicating that, controlling for share prices' role in proxying expectations of future output or consumption, higher stock market valuations are not expansionary, but rather contractionary. The mirror image of this result is that the expected growth in the stock market enters positively in the IS curve, even after future expected output or consumption are included in the equation. Overall, the main conclusion of the paper is that the evidence strongly points to the baseline New Keynesian IS curve not being a structural relationship.

The paper is organised as follows. In Section 2 we describe the baseline specification of the IS curve. In Section 3 we describe several possible extensions that will be tested. The data are described in Section 4 and the econometric approach in Section 5. In Section 6 results are presented and discussed. Section 7 concludes.

\section{Baseline specification}

The baseline specification is the standard New Keynesian hybrid (backward and forward looking) IS curve in a panel setting, which can be expressed as 


$$
y_{i t}=\alpha_{b} y_{i, t-1}+\alpha_{f} E_{t} y_{i, t+1}+\sigma_{r}\left(R_{i t}-E_{t} \pi_{i, t+1}-\bar{r}_{i}\right)+v_{i t}
$$

where $y$ is output, in deviation from the steady state, $R$ is a short term nominal interest rate, $\pi$ is a per-period inflation rate, $\bar{r}_{i}$ is the (unit specific) equilibrium (natural) real interest rate, $t$ is time and $i$ the country unit. Note that the baseline specification is also valid in an open economy context, see Kara and Nelson (2003) and Neiss and Nelson (2003), although the parameters (in particular $\sigma_{r}$ ) may be different. The presence of a backward-looking term may be justified with habit formation; see Fuhrer (2000). In most New Keynesian models the coefficient $\sigma_{r}$ is negative, but this is not necessarily the case in more elaborated models where changes in the nominal and real interest rate (here defined as $\left.r_{t}=R_{t}-E_{t} \pi_{t+1}\right)$ have an income effect, in addition to an inter-temporal substitution effect. I also estimate the same baseline equation, and all its extensions, for private consumption, since the behaviour of private consumption may deviate from that of the other main components of output, namely government consumption, investment and net exports.

In equation (1) I have assumed that the natural real interest rate is a constant. A generalisation for (1) would allow for a time-varying natural rate $\bar{r}_{i t}$, as follows

$$
y_{i t}=\alpha_{b} y_{i, t-1}+\alpha_{f} E_{t} y_{i, t+1}+\sigma_{r}\left(R_{i t}-E_{t} \pi_{i, t+1}-\bar{r}_{i t}\right)+v_{i t}
$$

In estimating equations like (1) and (2) on panel data I am assuming that the slopes are homogeneous across units. This may not be true in the data and it is a caveat to be kept in mind. However, I conduct an extensive analysis of robustness which also includes important elements of heterogeneity across countries, which should mitigate these concerns.

One important element of the analysis will be evaluating whether the New Keynesian IS curve is stable according to the Lucas definition, namely whether the preference parameters ${ }^{2}$ are (at least qualitatively) constant, not only over time but also across countries, controlling for random heterogeneity across units. In other words, if a preference parameter is systematically related to variable $X$ across units and over time, then the New Keynesian IS curve cannot be said to be structural and the variable $X$ will need to be somehow incorporated in structural models used for monetary policy analysis. This is

\footnotetext{
${ }^{2}$ In the baseline specification $\alpha_{b}, \alpha_{f}$ and $\sigma_{r}$.
} 
an analysis which is made considerably easier and more informative by the use of panel data, due to the higher cross sectional heterogeneity (at least on some dimensions) compared with the variation over time for many structural characteristics (say, financial and economic structure).

Finally, I also estimate a backward looking equation of the IS curve, which can be estimated with OLS:

$$
y_{i t}=\alpha_{b} y_{i, t-1}+\sigma_{r}\left(R_{i, t-1}-E_{t} \pi_{i t}-\bar{r}_{i t}\right)+v_{i t}
$$

Although not consistent with the New Keynesian IS curve based on first principles, a backward looking specification is very common in applied research and it is therefore a useful term of comparison for the baseline forward looking or hybrid specification.

\section{Extended version and heterogeneity analysis}

\subsection{Extended specifications}

In addition to the baseline equation in (2), I also estimate a number of alternative models which may be specified in a general form as follows,

$$
y_{i t}=\alpha_{b} y_{i, t-1}+\alpha_{f} E_{t} y_{i, t+1}+\sigma^{\prime} x_{i t}+v_{i t}
$$

where $x$ is a vector of (possibly forward-looking) variables; $\sigma$ is a vector of coefficients. I also consider the possibility of a non-linear specification where

$$
y_{i t}=\alpha_{b} y_{i, t-1}+\alpha_{f} E_{t} y_{i, t+1}+\sigma\left(x_{i t}\right)+v_{i t}
$$

and $\sigma\left(x_{i t}\right)$ is a (vector) non-linear function. In particular, I am interested in testing whether the relationship may be concave or convex rather than linear, since a non-linear specification is what almost always arises from structural models, at least before the log-linearization.

Among the driving variables that may appear in the IS curve, in addition to the real interest rate in the $x$ vector, I consider (i) two key asset prices (real stock and house prices), (ii) the real exchange rate and the terms of trade, to cater for open economy considerations, (iii) real money balances. 
The inclusion of asset prices should need no explanation, as there is a substantial literature on wealth effects of asset prices on consumption and output. The baseline specification for the model including asset prices (in addition to the real interest rate) is

$$
\sigma^{\prime} x_{i t}=\sigma_{q} q_{i t}+\sigma_{q}^{\prime} E_{t} q_{i, t+1}
$$

where $q$ is a log real asset price (in deviation from trend); I consider house and stock prices separately. This is a very general specification for which many structural models represent a special case. For example, the consumption-IS curve in Iacoviello (2004) has this type of specification for house prices; investment equations with a role for stock prices in a Tobin Q framework can also be cast as a special case of (5). Note that I estimate $\sigma_{q}$ and $\sigma_{q}^{\prime}$ separately but, provided that the restriction $\sigma_{q}=-\sigma_{q}^{\prime}$ is not rejected, the equation may also be interpreted as a function of expected returns on the considered asset, one period ahead.

The presence of the log real exchange rate and the log terms of trade (again, in deviation from trend) in the IS equation may be motivated by their potential impact on net exports, which is a component of output (net exports could have a spillover on consumption too, e.g. via employment effects). ${ }^{3}$ Moreover, in the presence of significant foreign assets and liabilities (and currency mismatches between them) exchange rate movements can also bring about valuation effects and hence influence consumption and output via wealth effects. ${ }^{4}$ Note that the second effect may go in the opposite direction than the first effect.

Finally, there is a considerable literature trying to include monetary aggregates in the IS curve; see e.g. Nelson $(2002,2003)$. I consider this possibility by adding a term

$$
\sigma^{\prime} x_{i t}=\sigma_{m} m_{i t}+\sigma_{m}^{\prime} E_{t} m_{i, t+1}
$$

where $m$ is log real money balances, and again, provided that $\sigma_{m}=-\sigma_{m}^{\prime}$ is not rejected, this may be interpretable as expected real money growth entering the IS curve.

\footnotetext{
${ }^{3}$ There is already a significant literature on th open economy IS curve. For structural treatments of the link between the (domestic) slope of the IS curve and openness see Gali and Monacelli (2005) and Erceg et al. (2007). Dees et al (2010) estimate an open-economy IS curve where also foreign output and the real effective exchange rate are included. For the terms of trade entering into the open economy IS curve, see Lubik and Schorfheide (2007). Kollmann (2009) finds that consumption may not be affected by real exchange rate movements if a significant share of consumers are 'hand to mouth'. Finally, Rodrik (2008) finds that, for developed countries, real exchange rate movements matter very little for the business cycle.

${ }^{4}$ See among others Benigno (2006).
} 
I follow the same logic for the backward-looking specification:

$$
y_{i t}=\alpha_{b} y_{i, t-1}+\sigma^{\prime} x_{i t}+v_{i t}
$$

where $x_{i t}$ now only includes variables up to time $t$.

\subsection{Country heterogeneity}

Another important element in order to assess the structural nature of the New Keynesian IS curve is the extent to which results for individual countries or for specific sub-groups of countries are consistent. In particular, I consider heterogeneity along several dimensions that appear to be the "plausible candidates" in terms of theoretical underpinnings. First, I estimate a baseline equation for large (G7) and smaller (non G7) countries, as well as for the largest five countries in the G7, taken individually. Second, I divide the whole group of countries in two sub-groups according to a number of structural indicators, dividing them up into countries with 'high' and 'low' values computed according to sample averages. These indicators are (i) trade openness and the net financial position vs. the rest of the world (Net Financial Assets, NFA), which should shed some light on the open economy dimension of the New Keynesian IS curve, in line with the considerations made above; (ii) a (rather crude) measure of economic structure, the weight of industry in the economy, as different sectors may be differently interest-sensitive ${ }^{5}$; (iii) measures of financial development, as the standard New Keynesian model is based on the assumption of seamless financial intermediation and free borrowing and lending; ${ }^{6}$ (iv) measures of household debt and household net worth (both total and short term), in particular for the consumption IS curve, in order to learn about the importance of wealth effects for consumption. ${ }^{7}$ The idea underlying this analysis is that if these structural characteristics matter they should lead to different IS curve estimates in countries with a comparatively

\footnotetext{
${ }^{5}$ See e.g. Dedola and Lippi (2005). Notably, a country with a higher share of manufacturing may be more investment-intensive, hence more dependent on external finance and exposed to interest rate changes.

${ }^{6}$ Muellbauer and Lattimore (1995) found little empirical evidence of a strong and stable negative real interest rate effect on consumption that many economists expect; and question whether this reflects the existence of a constrained financial system.

${ }^{7}$ Smith and Wickens (2006), among others, point out that the effect on consumption of an increase in interest rates depends on whether households hold net assets or net liabilities (total and / or short term). In other words, interest rate changes can also create valuation effects that depend on the financial structure of the economy.
} 
high or low reading for the chosen indicators. As mentioned in the Introduction, if this is the case then those structural characteristics should become a material element of a good theoretical model of the IS curve.

\section{Data}

In this study I use data from 22 OECD countries, including Australia, Belgium, Canada, Denmark, Finland, France, Germany, Ireland, Italy, Japan, Korea, Luxembourg, Mexico, the Netherlands, Norway, New Zealand, Portugal, Spain, Sweden, Switzerland, the United Kingdom and the United States. ${ }^{8}$ The sample period includes quarterly data from 1970:Q1 to 2009:Q4; overall, the panel has over 3,000 quarterly data for the main variables. Data include real GDP, private consumption, 3-month interbank nominal interest rates, the real effective exchange rate (deflated with the CPI), the terms of trade (defined as the ratio between export and import prices), stock prices, the CPI, and broad money (defined according to national definitions); residential property prices; consumer and industrial confidence; indicators of financial development and structure from the World Bank Database on Financial Development and Structure (see Beck and Demirgüc-Kunt 2009); a measure of trade openness (sum of imports and exports over GDP); Net Financial Assets (NFA) vs. the rest of the world; a measure of sectoral specialisation (the share of employment of the industrial sector); and some indicators of the financial structure of the household sector, from the OECD Financial Accounts. In particular, from the OECD data I construct a proxy for short term household net worth, defined as the difference between short term assets (currency and deposits, short term securities) and short term liabilities (short term loans).

Some of the data have an annual frequency, notably the house price data in some countries, and they have been converted into the quarterly frequency using a linear interpolation; this is a caveat that should be kept in mind in the continuation. Moreover, all data have been seasonally adjusted whenever appropriate. Table 1 provides an overview of the sources of the data, while Table 2 reports key descriptive statistics for all variables.

(insert Tables 1-2 around here)

\footnotetext{
${ }^{8}$ Reliable house price data are, however, not available for Korea and Mexico and OECD data for financial accounts are also not available for all countries.
} 


\section{The empirical model}

In order to cater for cross-sectional dependence, that is likely to be a serious concern for our estimation since business cycles are strongly correlated internationally, Pesaran (2006) suggested to use the CCEMG (Common Correlated Effect Mean Group) estimator. The method implies augmenting the main country-specific regressions with the cross section averages of both the dependent variable and the regressors. Pesaran shows, in particular, that the CCEMG is asymptotically unbiased under relatively general assumptions in models with a multi-factor error structure and where the unobserved common factors may also be correlated with the country-specific regressors (and the factor loadings differ across countries). I take a limited step in the direction of Pesaran's CCEMG estimator by including a measure of global output (consumption) as an exogenous variable in the output (consumption) IS curve, excluding the unit's output (consumption). ${ }^{9}$ The estimated equation therefore becomes

$$
y_{i t}=\alpha_{i t}+\alpha_{b} y_{i, t-1}+\alpha_{f} E_{t} y_{i, t+1}+\sigma^{\prime} x_{i t}+\theta y_{i t}^{*}+v_{i t}
$$

where $y^{*}$ represents the unit-specific measure of global foreign output (or consumption). The inclusion of the foreign output (consumption) term should arguably reduce the cross-sectional correlation of residuals and hence effectively address the problem of crosssectional dependence. Note that country fixed effects are always included.

The econometric analysis of panel data is significantly less problematic with covariance stationary data; I therefore de-trend output, private consumption, the real house and stock prices, real broad money, the real effective exchange rate, the real interest rate as well as the global, unit-specific measure of global output or consumption, using the one sided $\mathrm{HP}(1600)$ filter. The main advantage of the one sided filter is that it does not rely on future data and is therefore a more realistic picture of the business cycle as perceived at the time by economic agents. ${ }^{10}$

\footnotetext{
${ }^{9}$ Global output and consumption are computed using the GDP PPP weights as computed by the IMF, averages over the period 1980-2008.

${ }^{10}$ Note, however, that the data are not real time estimates.
} 
When applying an instrumental variables approach, necessary for the estimation of forward looking equations, the problem of potentially weak instruments needs to be dealt with, although for panel data this may be less of a problem than typically considered for non-panel estimations. ${ }^{11}$ Fuhrer and Rudebusch (2004) have emphasised that weak instruments may be at the root of the failure of the Generalised Method of Moments (GMM) to identify plausible estimates for the New Keynesian IS curve in the US ${ }^{12}$, and a similar debate has been raging for years on the estimation of the New Keynesian Phillips curve (see Gali, Gertler and Lopez Salido 2005). As will be evident later, however, standard tests of underidentification such as the Kleibergen-Paap test do not signal any problem from this side for the empirical analysis in this paper.

\section{Results}

\subsection{Backward looking IS curve}

We start with the estimates of the backward looking version of the IS curve. Although the backward looking specification is not consistent with the New Keynesian IS curve of most DSGE models, it is often estimated in practice (see e.g. Hafer and Jones 2008) and is therefore a useful starting point for future comparison. Results are reported in Table 3 for output and Table $3 A$ for private consumption. The tables report estimates using pooled OLS as well as, for comparison, estimates obtained allowing for heterogeneity using the random coefficients approach of Swamy (1970).

In the backward looking specifications for output and consumption reported in Table 3-3A detrended output is found to be a quite persistent process, with an autoregressive parameter above 0.5. In the output equation the real interest rate is generally negative, although only statistically significant in the random coefficients model. For consumption, the real interest rate is always statistically insignificant. By contrast, the real stock price and the real house price have a positive and statistically significant impact on both output and consumption, which is a quite common result in the literature (see e.g. Goodhart and Hofmann 2005). Finally, the squared term of the real interest rate, included in a

\footnotetext{
${ }^{11}$ Kao and Liu (2009) show that consistency can be established for panel data 2SLS when instruments are weak, unlike for non-panel data. More generally, see Stock et al. (2002) for a survey of the weak instruments problem.

${ }^{12}$ See also Fuhrer and Olivei (2006).
} 
nonlinear version of the IS curve in order to capture a possibly convex or concave shape, is statistically insignificant, as is a smoothed version of the real interest rate defined as a 4-quarter moving average of the real interest rate gap,

$$
\widetilde{r}_{t}=\frac{1}{4} \sum_{m=0}^{-3}\left(R_{t+m}-E_{t+m} \pi_{t+m+1}-\bar{r}_{i t}\right)
$$

(Table 3 and $3 \mathrm{a}$ around here)

\subsection{Baseline forward-looking IS curve}

It is well known that backward looking equations such as those estimated in the previous subsection may not be structural. I therefore turn to estimate the baseline hybrid New Keynesian IS curve as in equation (2). Since the equation is estimated using instrumental variables, an analysis of the appropriateness of the instruments is an important preliminary step. In Table $4(4 A)$ I therefore report the baseline estimates for output (consumption) using seven different sets of instruments. In addition to the own lags of the potentially endogenous variables (i.e. those appearing at time $t+1$ ) I also include foreign output (consumption) as well as industrial and consumer confidence. For all considered sets there is no evidence of weak instruments (the null of underidentification in soundly rejected), but there is evidence of overidentification from the $\mathrm{J}$ test. I therefore consider exactly identified models in the continuation of the analysis, but it is notable that estimates are very consistent across different sets of instruments. In particular, they signal that both output and consumption are mainly forward looking, and that the real interest rate is either insignificantly or wrongly signed throughout. This latter result stands in contrast with the results of the backward looking specification for output, emphasising once again that backward looking models can be a poor guide for a structural analysis.

(Table 4 and $4 \mathrm{a}$ around here) 


\subsection{Extended specifications}

In Tables 5-5A we extend the baseline specification to include additional terms as described in equation (4), in particular (i) the real effective exchange rate, (ii) the terms of trade, (iii) the real share price and house price, (iv) real broad money. As discussed in Section 3, these variables are included both in (detrended) log levels as well as in expected growth rates. ${ }^{13}$ House prices are included in a separate equation since they are not available for two countries (Mexico and Korea).

Again, for both output and consumption I find that the real interest rate is either insignificant or wrongly signed. A squared real interest rate term is also found to be insignificant. The real effective exchange rate and the terms of trade are significant in $\log$ levels; they indicate, as expected, that respectively a depreciation in the real effective exchange rate and a worsening of the terms of trade boost output. These variables are, however, generally insignificant in growth rates, with the exception of the terms of trade growth that is significant at the $10 \%$ confidence level in the consumption equation. What is notable is that the real stock price has the opposite sign compared with the backward looking specification; controlling for expected future output, higher stock prices depress, rather than boost output. As we will see later, this is a quite robust result. By contrast, the real house price is generally insignificant, again unlike in the backward looking specification. This suggests that the positive and significant coefficient for the real house price that has been obtained in the backward looking equation was probably due to house prices proxying expected future output. ${ }^{14}$

(Tables 5-5A around here)

\footnotetext{
${ }^{13}$ For each variable q I first test whether the restriction $\sigma_{q}=-\sigma_{q}^{\prime}$ cannot be rejected. Note that for illustrative purposes I include expected returns and growth rates as $E_{t} \Delta q_{t+1}=E_{t} q_{t+1}-q_{t}$. This implies that if $q$ is perceived to be, say, temporarily above equilibrium, then $E_{t} \Delta q_{t+1}$ is expected to be negative.

${ }^{14}$ See also Calomiris et al. (2009) for a similar result, which they dub the 'mythical' housing wealth effect.
} 


\subsection{Robustness}

All in all, expected future output, the real interest rate (but with the wrong sign) and expected stock market returns are the most significant variables in the different versions reported in Tables 5-5A. In this section I report some robustness analysis of the main equation. This is reported in Table 6 for output and Table $6 A$ for consumption. In particular, six variants of the equation are considered, namely (i) including more autoregressive lags for output (consumption), (ii) detrending variables using a linear trend rather than the HP filter, in order to assess the robustness to the detrending method used; (iii) restricting the sample to 1970-85 (before the Great Moderation) and (iv) 1986-2009 (after the Great Moderation); (v) excluding the global financial crisis of 2007-09, by ending the sample period in 2007Q2, since the behaviour of output and consumption may be different in crisis and non-crisis periods; (vi) excluding foreign output or consumption from the IS curve equations.

Overall, results are found to be pretty robust in the different variants considered. In particular, it is notable that the IS curve appears to be predominantly forward looking both before and after the Great Moderation, a result which stands in contrast with recent findings for the New Keynesian Phillips curve (Erceg et al. 2003; Benati 2008). The period around 1986 is characterised by a marked change in the monetary policy regime in most advanced countries; this result therefore implies that the monetary policy regime matters little for the degree of forward-lookingness of the IS curve, unlike for the Phillips curve.

At the same time, there are some interesting exceptions. The real interest rate is found to be positive and significant before 1986, and insignificant thereafter. In line with the idea that globalisation has made individual economies more integrated in the most recent decades, I find that the influence of foreign output and consumption is between one and a half and twice as much after 1986 than it was before then, suggesting more interdependence across countries.

(Tables 6 and 6A around here) 


\subsection{Country heterogeneity}

As a final step, we turn to analyse heterogeneity at country level. It should be noted that this part of the analysis should be considered not only as a robustness check but also part and parcel of the main thrust of the paper, which is to evaluate whether it is appropriate to conclude that the New Keynesian IS curve is a 'structural' relationship in the meaning of Lucas (1976). It can be argued that a truly structural relationship should not contemplate marked differences at country level, at least in qualitative terms. If, for example, the fact that $\sigma_{r}<0$ is a key and universal element of the theory, then we should find $\sigma_{r}<0$ in at least a strong majority of the countries.

In this section I conduct two types of heterogeneity analysis. I first look at results for individual countries and country groups determined according to size. This is reported in Tables 7-7A for output and consumption, where I estimate the main equation for (i) G7 countries, (ii) five individual G7 countries and (iii) non G7 countries (hence smaller) countries. Three interesting results emerge from this analysis. First, there is strong evidence of weak instruments for individual country estimates, especially for output. ${ }^{15}$ This underlines the importance of estimating the relationship from a multicountry perspective. Second, foreign output (consumption) matters more for the smaller non G7 countries than for the larger G7 countries, which accords well with intuition. Last, the real interest rate is positive and significant in the G7 countries, but negative and significant for non G7 countries. Again, this is a strong indication that a negative coefficient for the real interest rate is probably not a robust and structural feature of the IS curve.

(Table 7-7A around here)

The second part of the heterogeneity analysis is to evaluate whether structural differences across countries matter for the estimated IS curve. I therefore split the country group in two subgroups with 'high' (i.e. above the median) and 'low' (i.e. below the median) readings of the structural indicators. The averages for the considered variables are reported in Table 8, together with the number of countries in each sub-group. To illustrate the objectives of this analysis, consider the first indicator, trade openness. Countries

\footnotetext{
${ }^{15}$ This is also the case when including additional instruments (not reported for brevity).
} 
are divided between those who are more or less open, and the same IS curve model is estimated for both subgroups. If openness matters for the parameters in the IS curve, this should show up in a significantly different estimate for the two subgroups. The structural characteristics can be divided into four groups: first, trade openness and Net Financial Assets (NFA) over GDP; second, a variable of economic structure (the weight of industry in the economy); third, measures of financial development (the ratio of liquid liabilities, private credit and stock market capitalisation to GDP); and finally, indicators capturing the financial structure of the household sector (household net worth, household short term net worth, and household debt, all as a ratio to GDP). As can be seen from Table 8, there is considerable difference in the cross country averages for the considered indicators. For example, countries with 'low' NFA have an average negative balance of $25 \%$ of GDP, while those with 'high' NFA have a positive balance of $27 \%$ of GDP; countries with 'low' household debt have a ratio of less than $50 \%$ to GDP, while those with 'high' debt have 86\%. ${ }^{16}$ Note that I now estimate the IS curve for the period after 1986 only, since most of the structural indicators are anyway available only for the most recent decades.

(Table 8 around here)

Table 9 reports estimates for output; some interesting results emerge. First, the change in the real effective exchange rate is significant, with a negative sign, only in more open economies, which is sensible. It is also significant, and with the opposite sign, in countries with low (often negative) NFA. These results indicate that an exchange rate depreciation today, which is expected to be reversed tomorrow, boosts output in more open countries, but reduces output in countries with low or negative NFA, possibly due to valuation effects. Note however that I find no evidence that the interest rate elasticity of output is significantly larger in more open economies due to an expenditure switching effect, as argued e.g. in Erceg et al. (2007).

\footnotetext{
${ }^{16}$ One caveat to this type of approach is that data are not available for all countries over the same sample period. However, even when computing the sample averages over the most recent period, when data are available for almost all countries, the classification of individual countries to the group of 'high' or 'low' is very little affected.
} 
Stock returns are, also as expected, significant only in countries with a high stock market capitalisation. Results for the measures of financial development are not clear cut; in particular, there is no clear evidence that the New Keynesian IS curve works "better" - in particular in relation to the negative sign of the real interest rate - in financially more developed countries. Hence, the evidence does not appear to be consistent with the idea that the effect of the real interest rate on output and consumption is stronger at higher stages of financial development (Muellbauer and Lattimore 1995).

Table $9 A$ reports results for private consumption according to indicators of household financial structure. Household debt does not affect the qualitative features of the equation to a great extent. Household net worth appears to matter for the coefficient on the real interest rate, which is negative and significant (though only at the $10 \%$ significance level) in countries with low net worth, while it is insignificant in countries with high net worth. A possible explanation is that in former countries the inter-temporal substitution prevails, while in the latter countries the wealth effect plays a counterbalancing role. As far as short term household net worth is concerned, in countries with high short term household net worth the real interest rate is positively signed, suggesting the prevalence of a wealth effect in those countries, while it is insignificant in countries with low short term net worth. Taken together, this evidence suggest that wealth effects tend to dominate over, or at least compensate, inter-temporal substitution effects in the forward looking IS curve, and that this result is not greatly affected by the degree of financial development of the individual countries.

(Table 9-9A around here)

\subsection{Some caveats and qualifications}

The econometric analysis conducted in this paper and the results obtained are subject to various caveats and qualifications that should be kept in mind. First, some variables are available only at an annual frequency and it was necessary to interpolate them in order to obtain data at a quarterly frequency. This is notably the case for house prices, the results for which need therefore to be interpreted with caution. Second, it is not necessarily 
the case that an empirical de-trending as carried out in this paper corresponds to the removal of a trend as is defined in, and consistent with, DSGE models. If the empirical de-trending is imperfect and inconsistent with the underlying theory, then the results of the analysis could be spurious. In the case of the New Keynesian IS curve this could be particularly worrying if de-trended output is affected by productivity shocks, since these shocks (unlike, say, monetary policy shocks) tend to make the real interest rate procyclical (Martens 2010). The evidence presented in this paper is therefore not necessarily inconsistent with the idea that monetary policy shocks have an impact on output, a fact for which there is ample evidence. The ideal situation would be to estimate the parameters of the Euler equation and the corresponding gaps simultaneously in the context of a fullblown DSGE model, but this is very difficult in practice and cannot be done without imposing strong priors on the parameters. Finally, the analysis in the paper might be subject to mis-measurement in the ex ante real interest rate. Indeed, Inoue, Kilian and Kiraz (2009) find, based on survey data, that household consumption responds more to perceived, rather than actual real interest rates. It should be noted, however, that the idea of a systematic departure between perceived and actual real interest rates is also inconsistent with the basic set-up of New Keynesian models. Nonetheless, this is an interesting conjecture that could be taken up in future work.

\section{Conclusions}

This paper has evaluated various specifications of the New Keynesian IS curve on panel data from 22 OECD countries over a sample period of almost 40 years. Overall, I find that there is strong and robust evidence that both consumption and output are predominantly forward-looking, in line with New Keynesian models, but that the key forcing variable in such models, the ex ante real interest rate, is often statistically insignificant or wrongly signed. I also find that household net worth, in particular short term net worth, plays a significant role in determining the relative importance of wealth and intertemporal substitution effects in the IS curve. It would therefore be important to integrate this variable in baseline DSGE models used for monetary policy analysis.

As recalled in the Introduction, the negative result concerning the real interest rate as a driving variable of the IS curve is certainly not new in the literature. The main 
contribution of the present paper is to present substantial international evidence documenting this fact and to test its robustness in a number of ways. In particular, because of the large database used, concerns on weak instruments and small samples cannot be a good explanation of the paper's findings. Even taking into account the caveats and qualifications accompanying the results, this paper therefore suggests that there may be something seriously wrong with the New Keynesian IS curve, a result which should be of great interest for macroeconomics and monetary economics. More importantly, with the present state of knowledge policy makers are well advised to take a skeptical view on models which have a standard inter-temporal IS curve at their core. 


\section{References}

[1] Angeloni, I. and M. Ehrmann (2007): "Euro area inflation differentials", The B.E. Journal of Macroeconomics, $7,1$.

[2] Beck, T. and A. Demirgüc-Kunt (2009): "Financial institutions and markets across countries and over time - data and analysis", World Bank, working paper.

[3] Benati, L. (2008): "Investigating inflation persistence across monetary regimes", Quarterly Journal of Economics, 123, 3, pp. 1005 - 1060.

[4] Benigno, P. (2006): "Are valuation effects desirable from a global perspective?", NBER Working Paper No. 12219.

[5] Calomiris, C., Longhofer, S. D. and W. Miles (2009): "The (mythical?) housing wealth effect", NBER Working Paper No. 15075.

[6] Campbell, J. and N. Mankiw (1991): "The response of consumption to income: A cross country investigation", European Economic Review, 35, pp. 715-721.

[7] Dedola, L. and F. Lippi (2005): "The monetary transmission mechanism: Evidence from the industries of five OECD countries," European Economic Review, 49, 6, pp. 1543-1569.

[8] Dees, S., Pesaran, M. H., Smith, L. V. and R. P. Smith (2010): "Supply, demand and monetary policy shocks in a multi-country New Keynesian model", mimeo.

[9] Erceg, C. and A. T. Levin (2003): "Imperfect credibility and inflation persistence," Journal of Monetary Economics, 50, 4, pp. 915-944.

[10] Erceg, C., Gust, C. and D. Lopez Salido (2007): "The Transmission of Domestic Shocks in Open Economies", NBER Working Paper No. 13613.

[11] Fuhrer, J. (2000): "Habit formation in consumption and its implications for monetary policy models", American Economic Review, 90, pp. 367-350. 
[12] Fuhrer, J. C. and G. P. Olivei (2004): "Estimating forward-looking Euler equations with GMM estimators: an optimal instruments approach", Federal Reserve Bank of Boston Research Paper Series No. 04-2.

[13] Fuhrer, J. C. and G. D. Rudebusch (2004): "Estimating the Euler equation for output", Journal of Monetary Economics, 21, pp. 1133-1153.

[14] Gali, J., Gertler, M. and J. D. Lopez-Salido (2005): "Robustness of the estimates of the hybrid New Keynesian Phillips curve", Journal of Monetary Economics, 52, pp. 1107-1118.

[15] Gali, J. and T. Monacelli (2005): "Monetary Policy and Exchange Rate Volatility in a Small Open Economy", Review of Economic Studies, Vol. 72, No. 3, pp. 707-734.

[16] Goodhart, C. A. E. and B. Hofmann (2005): "The IS curve and the transmission of monetary policy: is there a puzzle?", Applied Economics, 37, pp. 29-36.

[17] Hafer, R. W., Haslag, J. and G. Jones (2007): "On money and output: is money redundant?", Journal of Monetary Economics, 54, pp. 945-954.

[18] Hafer, R. W. and G. Jones (2008): "Dynamic IS curves with and without money: an international comparison", Journal of International Money and Finance, 27, 4, pp. 609-616.

[19] Inoue, A., Kilian, L. and F. B. Kiraz (2009): "Do Actions Speak Louder Than Words? Household Expectations of Inflation Based on Micro Consumption Data," Journal of Money, Credit and Banking, 41, 7, pp. 1331-1363.

[20] Kao, C. and L. Liu (2009): "Consistent estimation with weak instruments in panel data", working paper.

[21] Kara, A. and E. Nelson (2004): "International Evidence on the Stability of the Optimizing IS Equation", Oxford Bulletin of Economics \& Statistics, Vol. 66, No. S1, pp. 687-712.

[22] Kolmann, R. (2009): "Limited asset market participation and the consumption-real exchange rate anomaly", CEPR Discussion Paper No. 7452. 
[23] Iacoviello, M. (2004): "Consumption, house prices, and collateral constraints: a structural econometric analysis," Journal of Housing Economics, 13, 4, pp. 304-320.

[24] Lubik, T. A. and F. Schorfheide (2007): "Do central banks respond to exchange rate movements? A structural investigation" Journal of Monetary Economics, 54, 4, pp. 1069-1087.

[25] Lucas, R. (1976): "Econometric Policy Evaluation: A Critique", in Brunner, K.; Meltzer, A., The Phillips Curve and Labor Markets, Carnegie-Rochester Conference Series on Public Policy, 1, pp. 19-46.

[26] Martens, E. (2010): "Structural shocks and the comovement between output and interest rates", Federal Reserve Board Finance and Economics Discussion Series No. 2010-21.

[27] Muellbauer, J. and R. Lattimore (1995): "The consumption function" in Pesaran, M. H. and M. Wickens (eds.), Handbook of Applied Econometrics: Macroeconomics, Blackwell, Oxford.

[28] Muellbauer, J. (2010): "Household decisions, credit markets and the macroeconomy: implications for the design of central bank models", BIS Working Paper No. 306.

[29] Neiss, K. and E. Nelson (2003): "The real interest rate gap as an inflation indicator", Macroeconomic Dynamics, 7, pp. 239-262.

[30] Nelson, E. (2002): "Direct effects of base money on aggregate demand: theory and evidence", Journal of Monetary Economics, 49, pp. 687-708.

[31] Nelson, E. (2003): "The future of monetary aggregates in monetary policy analysis," Journal of Monetary Economics, 50, 5, pp.1029-1059.

[32] Pesaran, H. (2006): "Estimation and inference in large heterogeneous panels with a multifactor error structure", Econometrica, 74, 4, pp. 967-1012.

[33] Rodrik, D. (2008): "The real exchange rate and economic growth", Brookings Papers on Economic Activity, 2, pp. 365-412. 
[34] Shiller, R. (2007): "Low Interest Rates and High Asset Prices: An Interpretation in Terms of Changing Popular Economic Models", NBER Working Paper No. 13558.

[35] Smith, P. N. and M. Wickens (2006): " The New Consensus in Monetary Policy: Is the NKM fit for the purpose of inflation targeting?," CDMA Conference Paper Series 0610, Centre for Dynamic Macroeconomic Analysis.

[36] Stock, J., Wright, J. H. and M. Yogo (2002): "A survey of weak instruments and weak indentification in Generalized Methods of Moments", Journal of Business and Economic Statistics, 20, 4, pp. 518-529.

[37] Swamy, P. A. V. B. (1970): "Efficient inference in a random coefficient regression model", Econometrica 38, pp. 311-323. 
TABLE 1. Sources of the data

\begin{tabular}{|c|c|}
\hline Data & Source \\
\hline $\begin{array}{l}\text { Real GDP, private consumption, } \\
\text { short-term nominal interest rate, real } \\
\text { effective exchange rate, stock prices, } \\
\text { CPI, broad money, terms of trade }\end{array}$ & $\begin{array}{l}\text { OECD Economic Outlook, Main Economic } \\
\text { Indicators } \\
\text { 1970:Q1-2009:Q4 }\end{array}$ \\
\hline Industrial and consumer confidence & OECD Main Economic Indicators, Eurostat, BIS* \\
\hline House prices & $\begin{array}{l}\text { ECB Residential Property Prices database, } \\
\text { Bank for International Settlements, national sources** }\end{array}$ \\
\hline $\begin{array}{l}\text { Indicators of financial development } \\
\text { - ratio of liquid assets over GDP; } \\
\text { - ratio of total private credit over GDP; } \\
\text { - stock market capitalisation over GDP. }\end{array}$ & $\begin{array}{l}\text { World Bank Database on Financial } \\
\text { Development and Structure*** } \\
1960-2008 \text { (annual) }\end{array}$ \\
\hline $\begin{array}{l}\text { Trade openness } \\
\text { (share of exports+imports over GDP) }\end{array}$ & OECD Economic Outlook \\
\hline Size: world GDP weight at PPP & IMF World Economic Outlook \\
\hline $\begin{array}{l}\text { Sectoral specialisation: share of employed } \\
\text { in the industrial sector }\end{array}$ & OECD Main Economic Indicators**** \\
\hline $\begin{array}{l}\text { Household net worth (total and short term), } \\
\text { household debt as a share of GDP }\end{array}$ & $\begin{array}{l}\text { Elaborations on OECD Financial Accounts***** } \\
\text { (annual) }\end{array}$ \\
\hline $\begin{array}{l}\text { Net Financial Assets (NFA) } \\
((\text { external assets-external liabilities)/GDP) }\end{array}$ & $\begin{array}{l}\text { IMF World Economic Outlook } \\
\text { (annual) }\end{array}$ \\
\hline
\end{tabular}

* Data not available for Korea, Mexico and Norway for consumer confidence.

** Data not available for Korea and Mexico.

*** See Beck and Demirguc-Kunt (2009).

**** Data not available for Luxembourg and Mexico.

***** Data not available for Australia and New Zealand. 


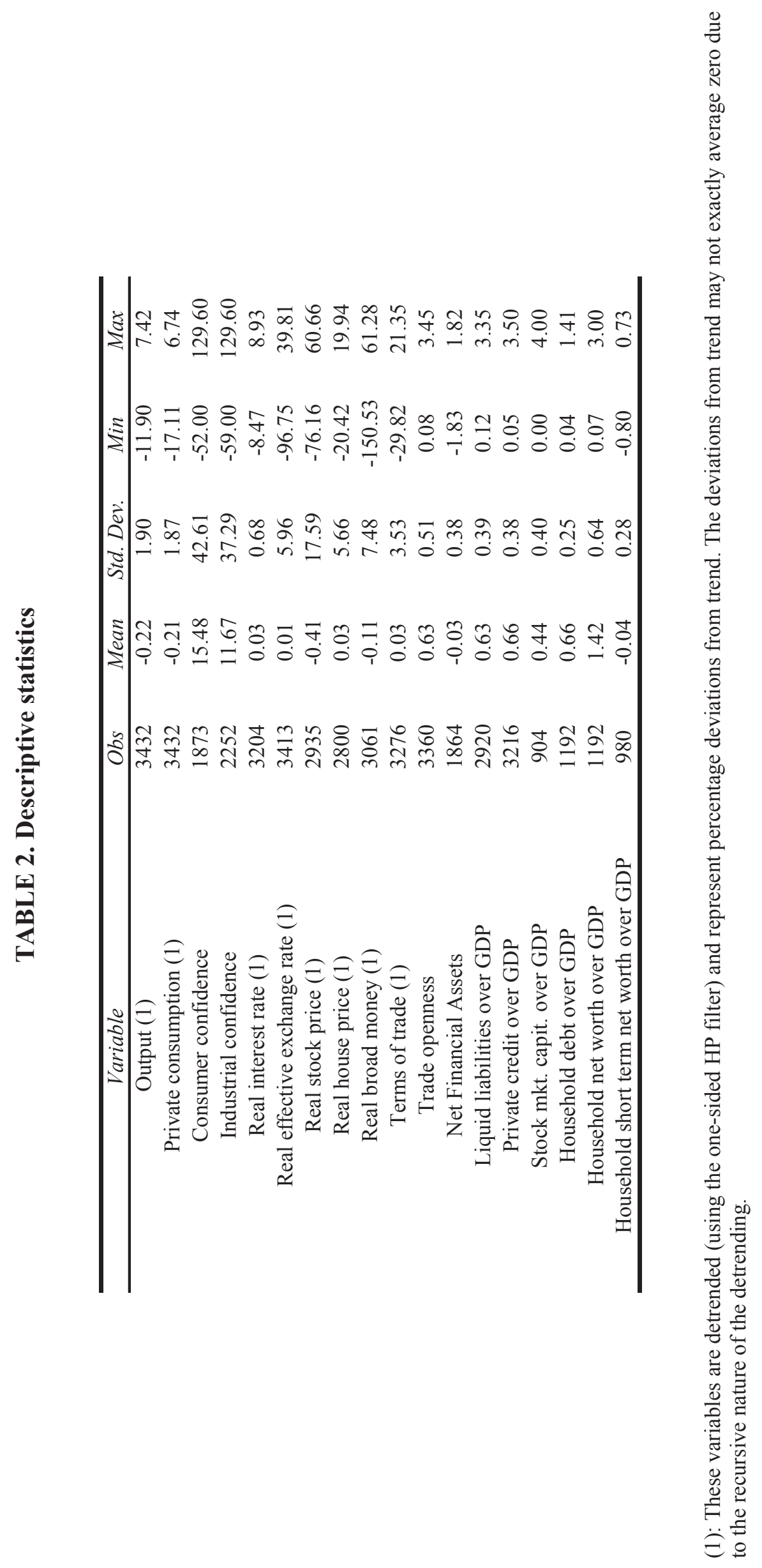




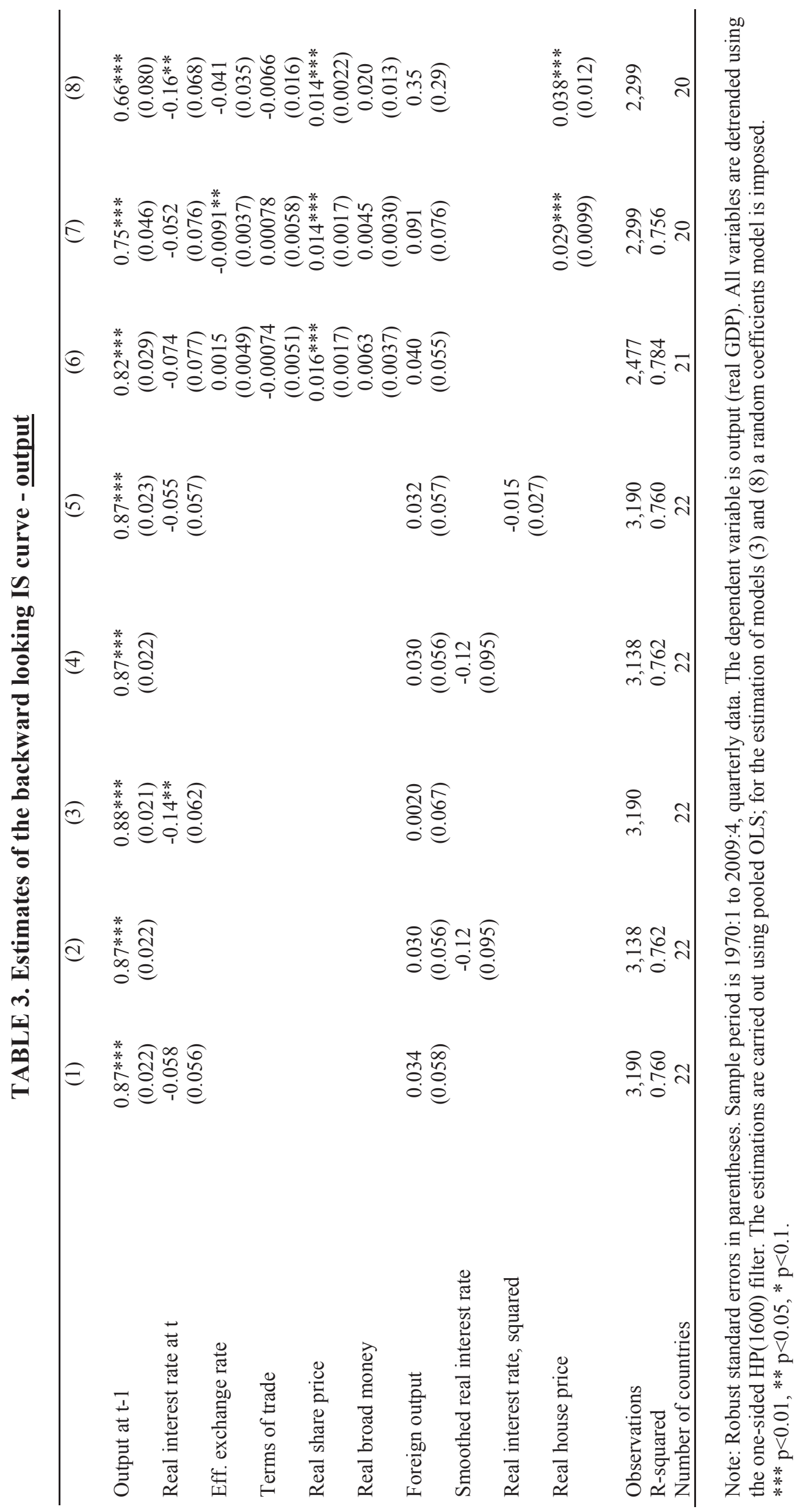




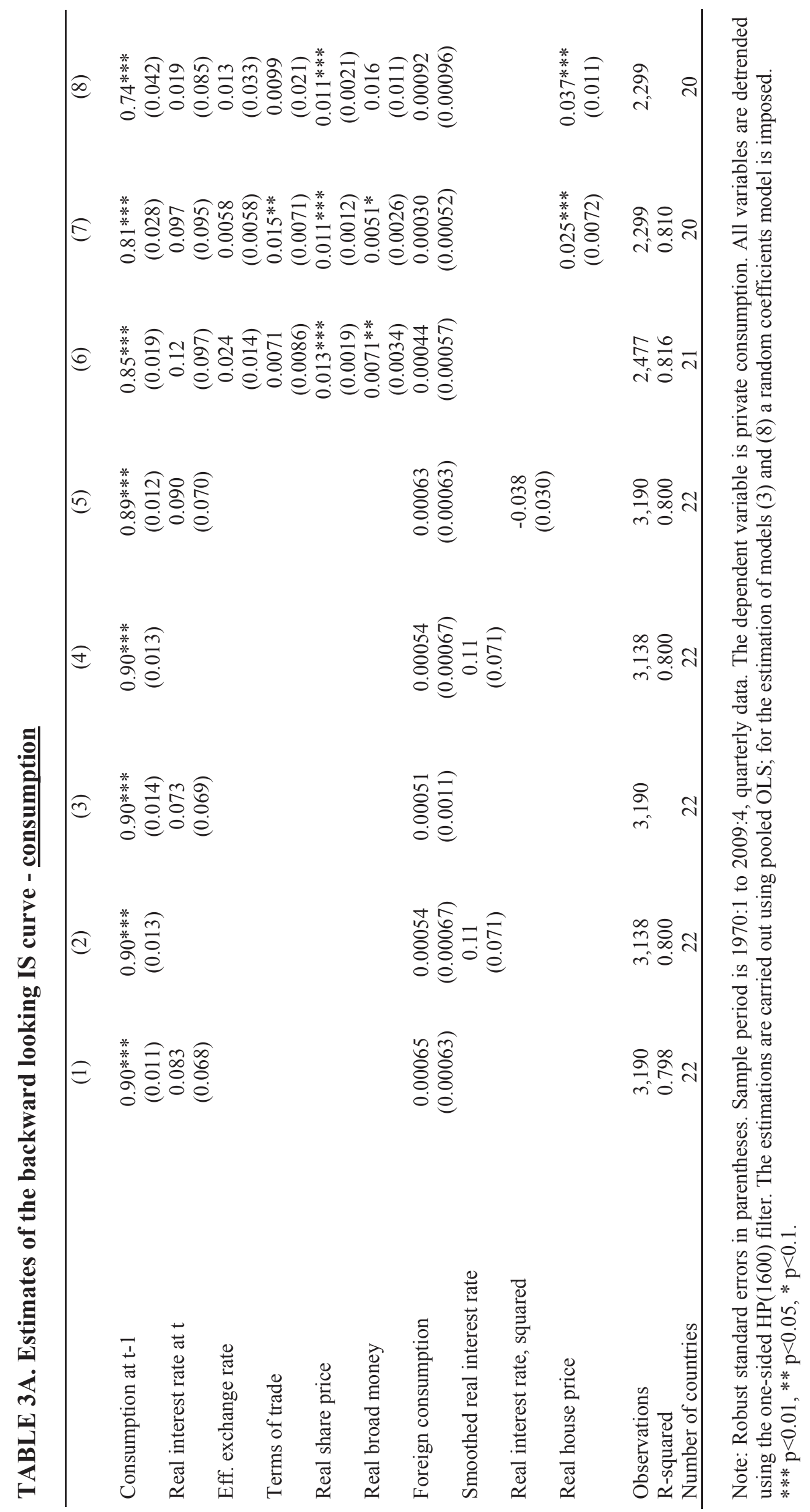




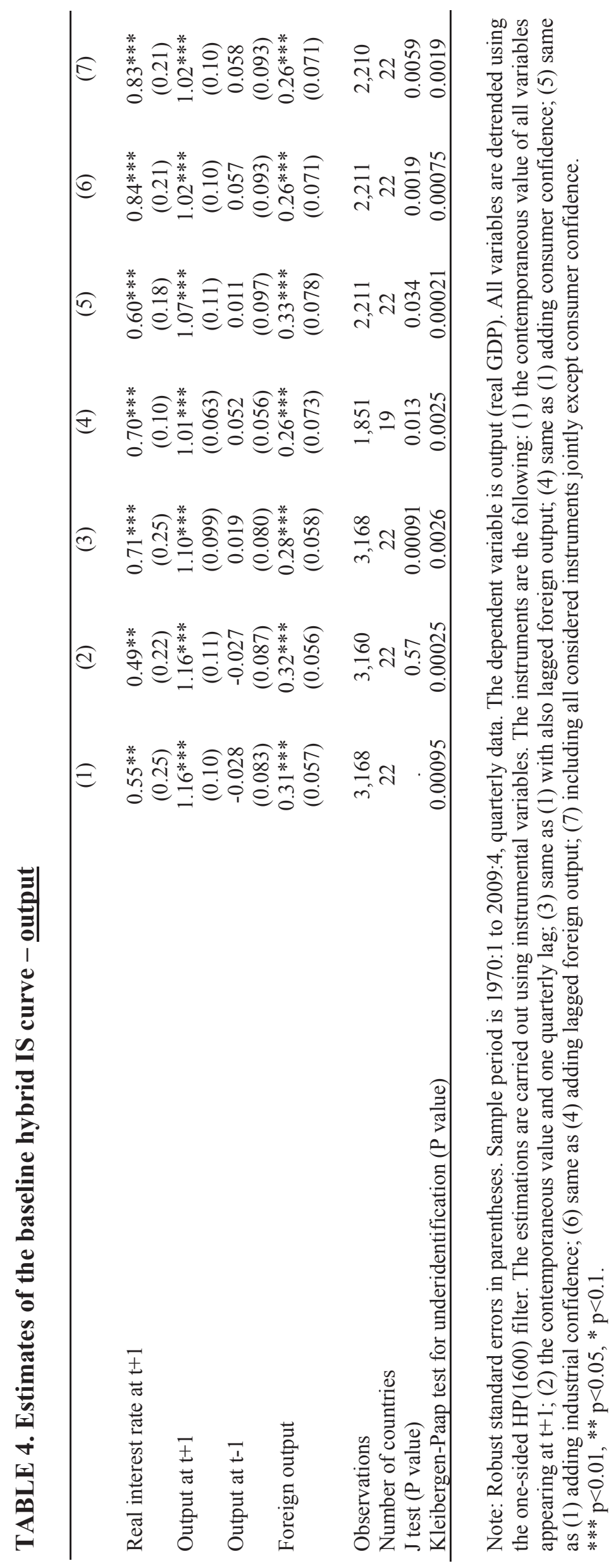




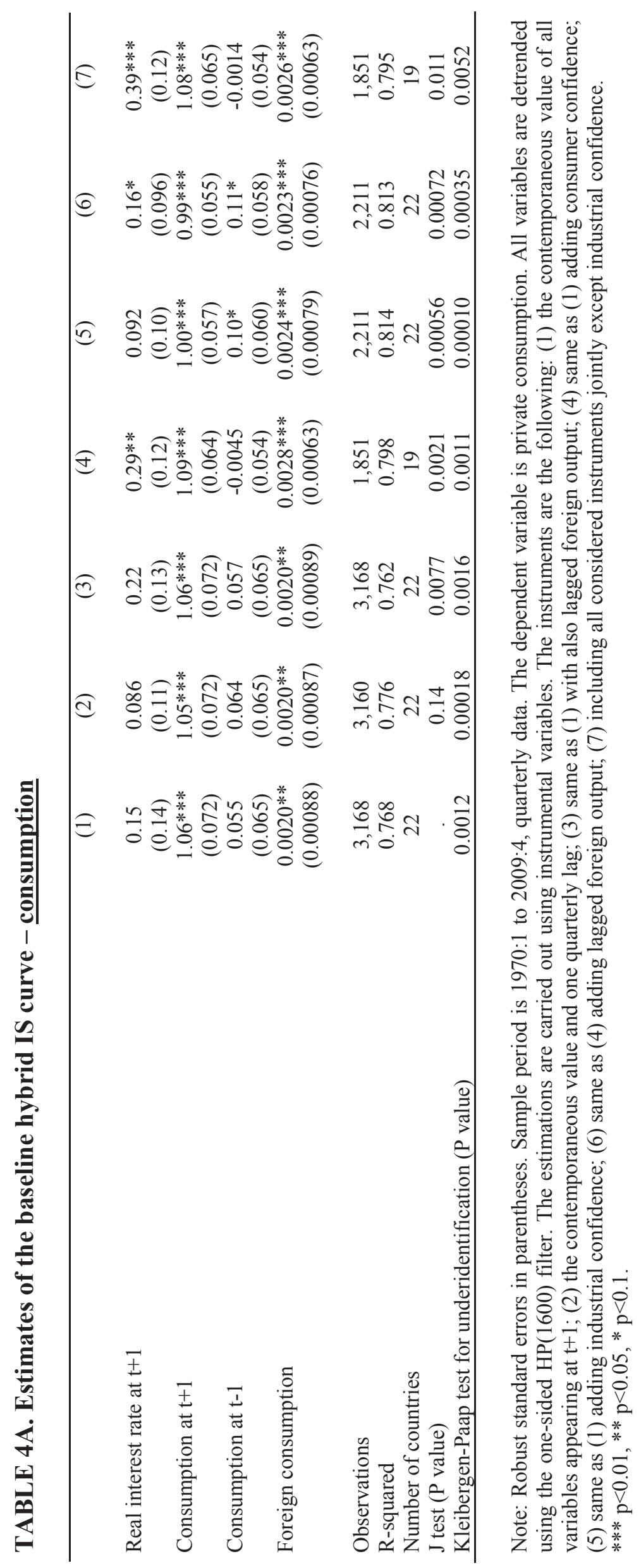




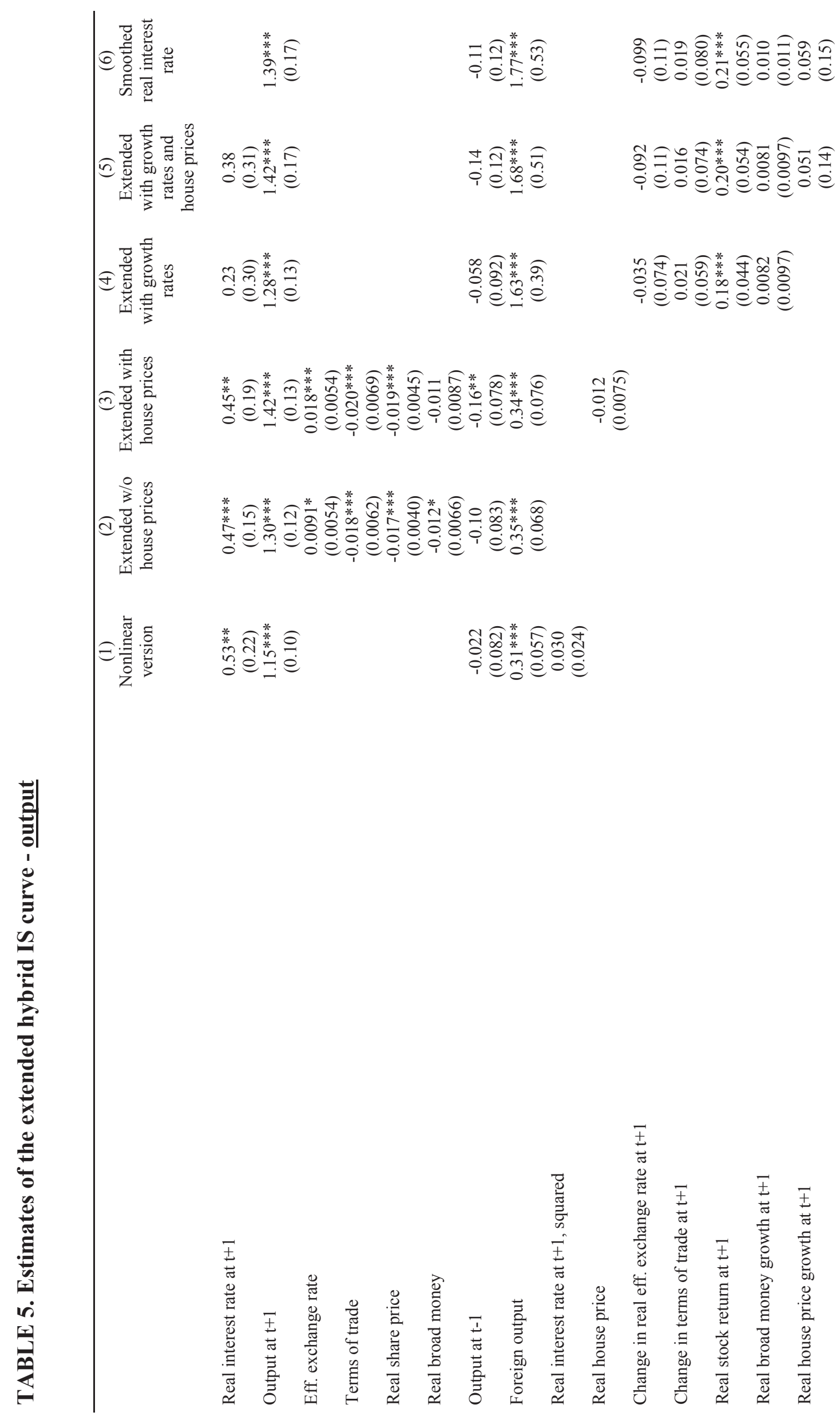




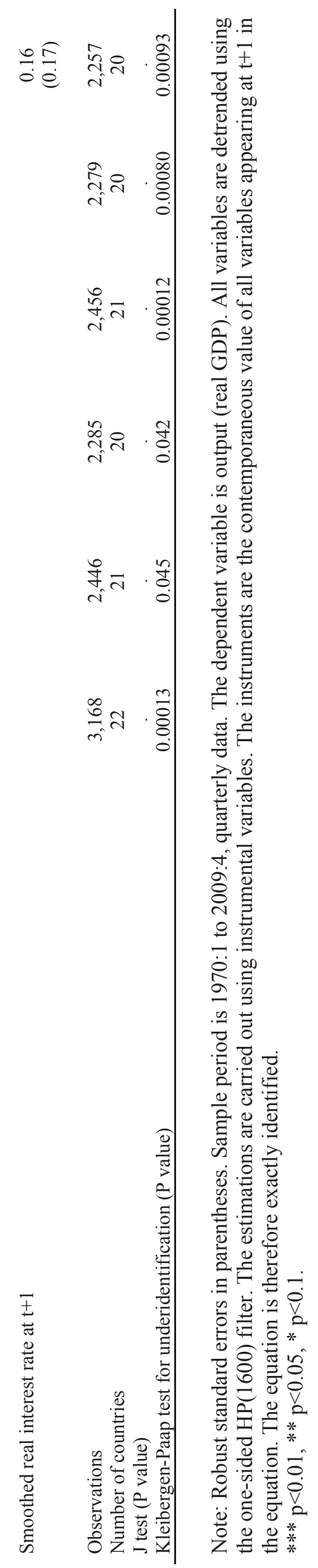




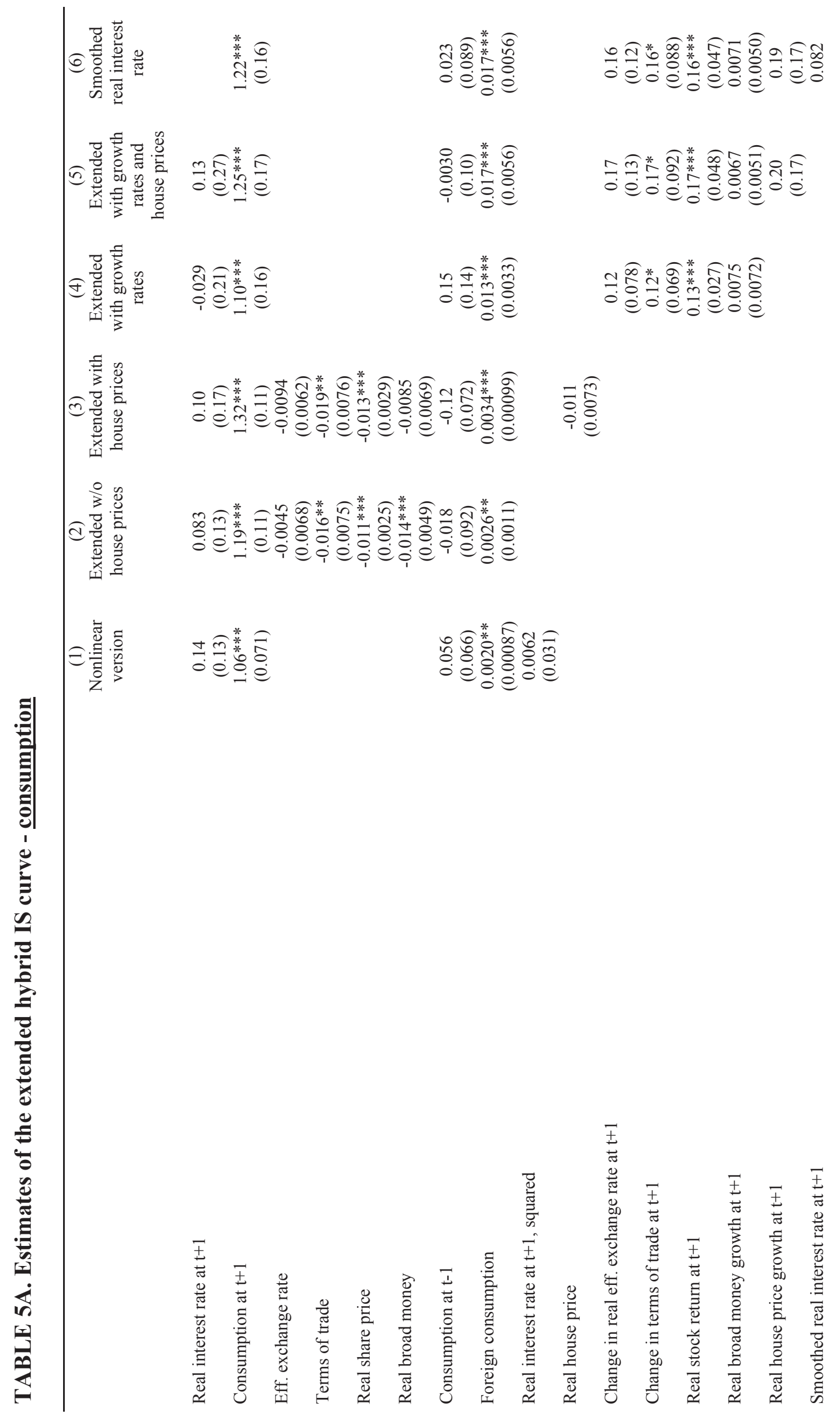




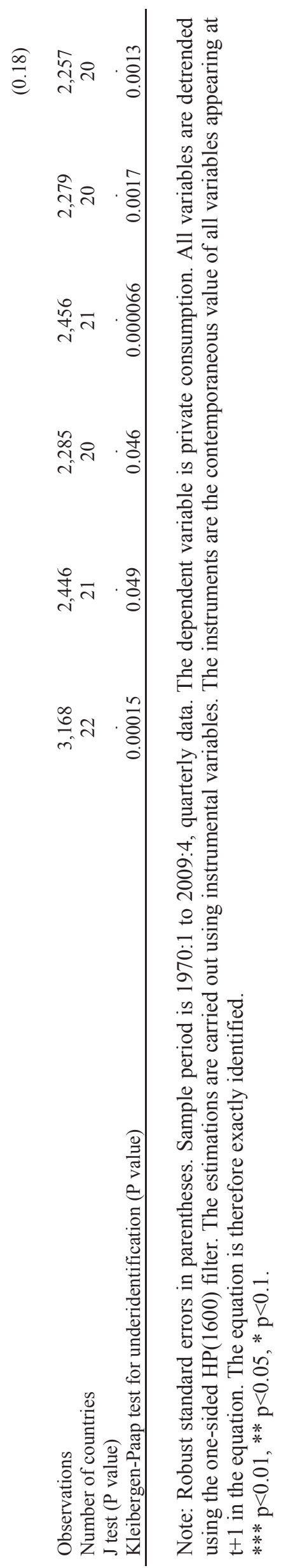

Working Paper Series № 1236 


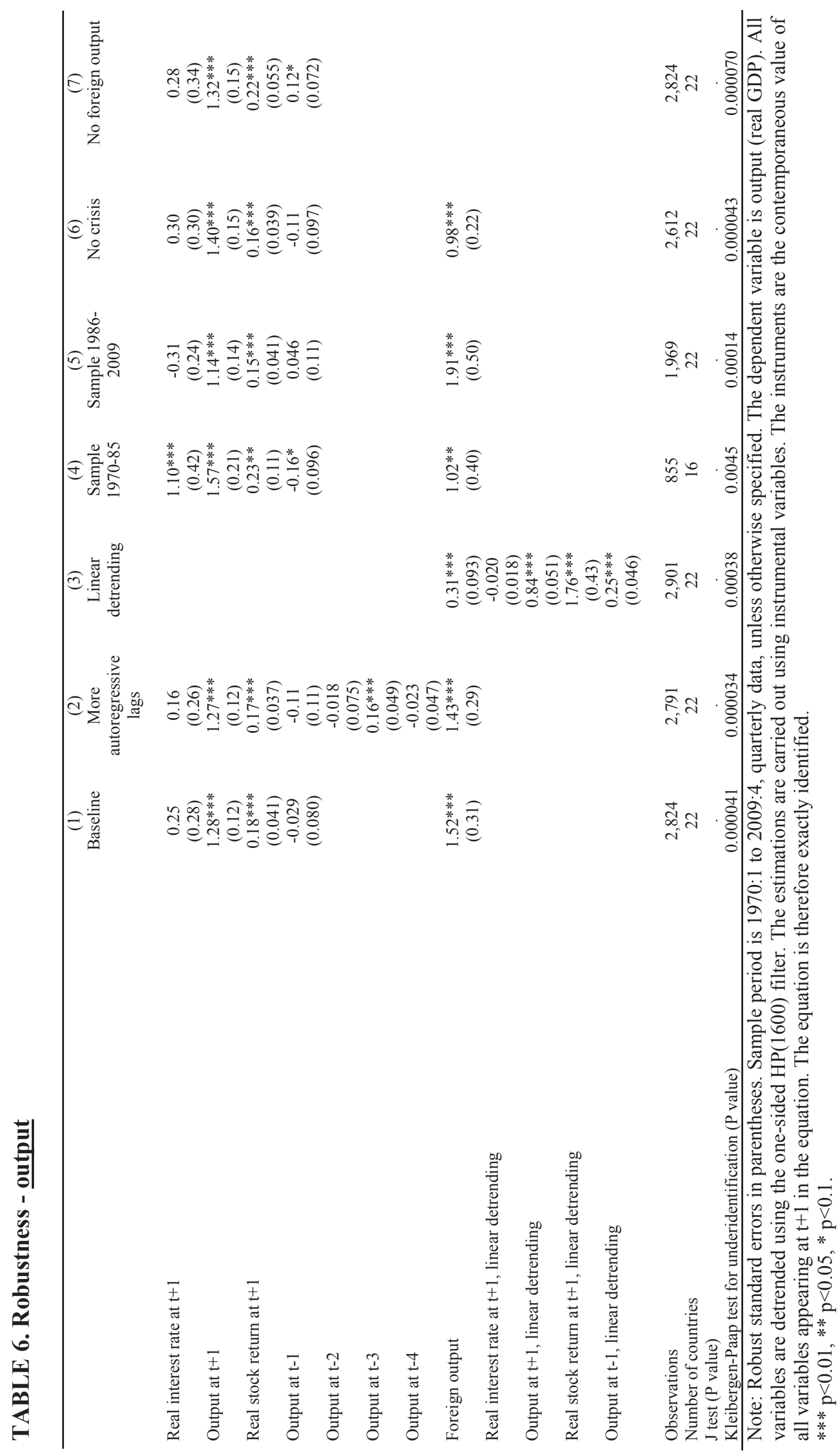




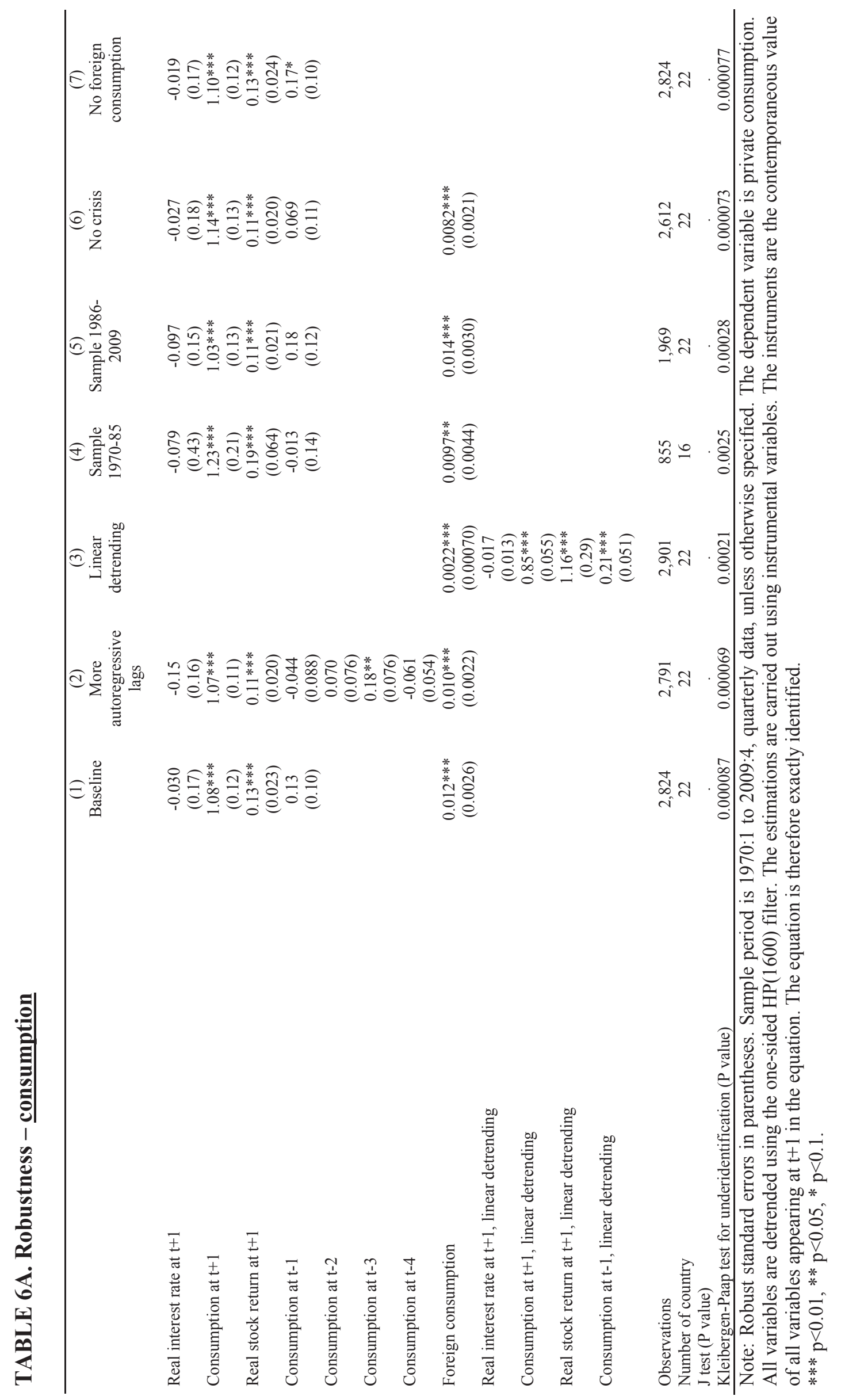




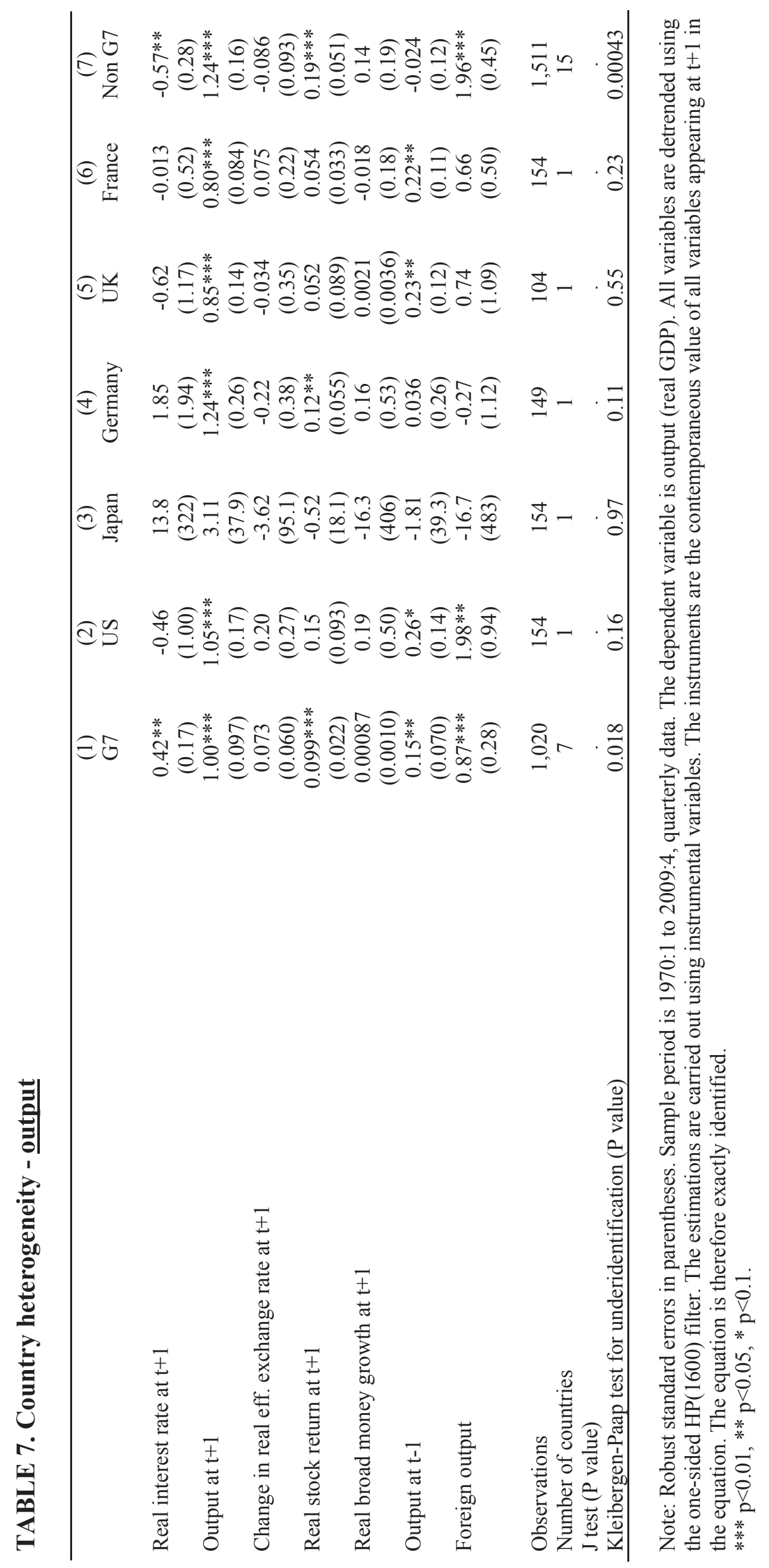




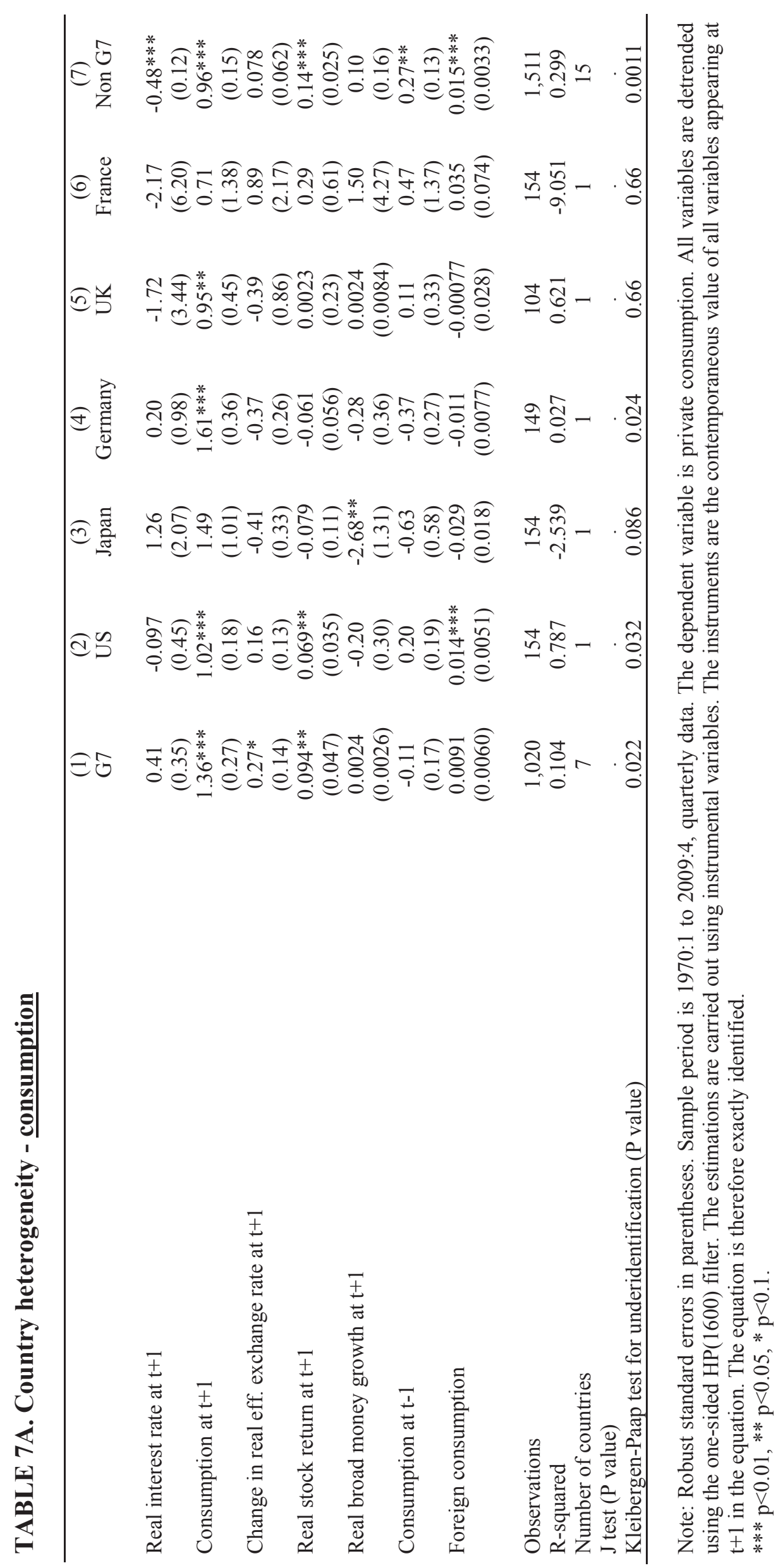


TABLE 8. Structural indicators: group averages

\begin{tabular}{ccccc} 
& Average low & $\mathrm{n}$ & Average high & $\mathrm{n}$ \\
\hline Trade openness & 0.29 & 11 & 0.72 & 11 \\
Weight of industry & 0.25 & 10 & 0.32 & 10 \\
NFA/GDP & -0.25 & 11 & 0.27 & 10 \\
Liquid liab./GDP & 0.44 & 11 & 0.96 & 11 \\
Private credit/GDP & 0.44 & 11 & 0.88 & 11 \\
Stock mkt. cap./GDP & 0.24 & 11 & 0.78 & 10 \\
Household debt/GDP & 0.49 & 10 & 0.86 & 9 \\
Household net worth/GDP & 0.82 & 10 & 1.91 & 9 \\
Household short term net worth/GDP & -0.29 & 8 & 0.17 & 8 \\
\hline
\end{tabular}

Note: Based on a classification of 22 OECD countries according to the average value of the indicator for the sample period in which data are available for each country. Countries are classified as 'high' or 'low' according to whether their sample average is above or below the country median. For some indicators data data are not available for some countries, hence the total number of countries can be below 22. The weight of industry in the economy is proxied by the share of the employment in industry over total employment. 


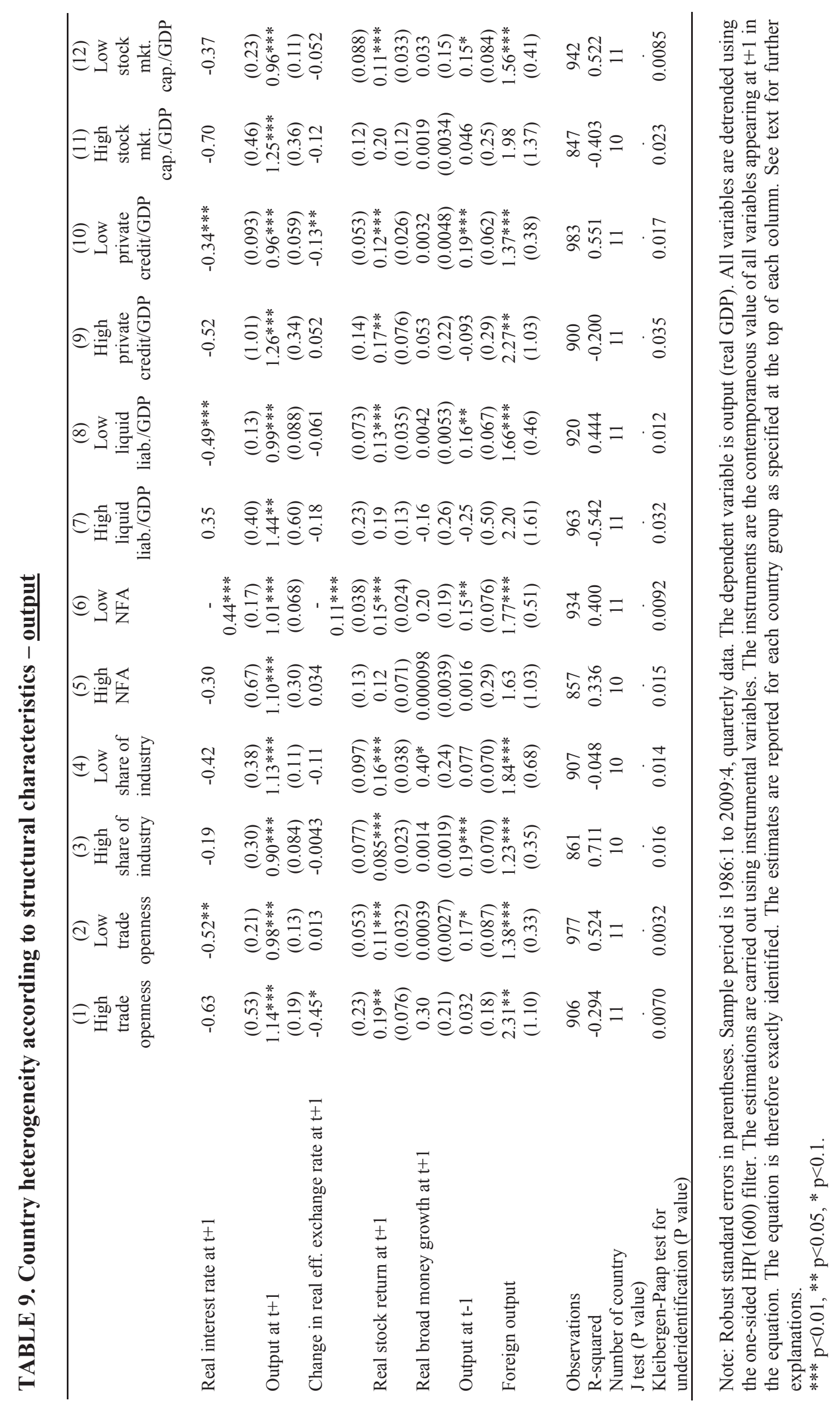




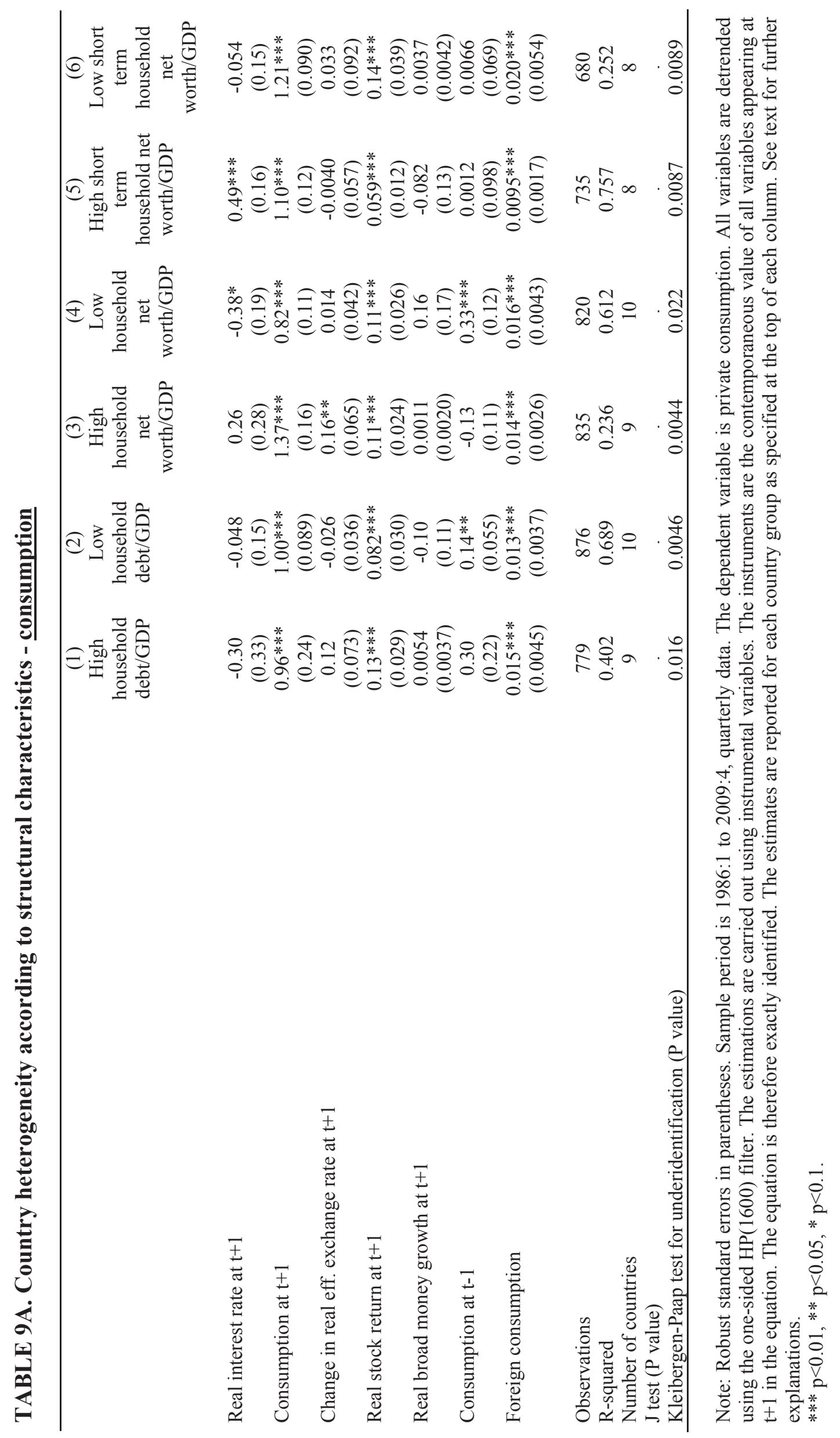


